\title{
Linkages between ozone-depleting substances, tropospheric oxidation and aerosols
}

\author{
A. Voulgarakis ${ }^{1, *}$, D. T. Shindell ${ }^{1}$, and G. Faluvegi ${ }^{1}$ \\ ${ }^{1}$ NASA Goddard Institute for Space Studies and Columbia University Center for Climate Systems Research, New York, USA \\ *now at: Department of Physics, Imperial College, London, UK
}

Correspondence to: A. Voulgarakis (a.voulgarakis@imperial.ac.uk)

Received: 31 July 2012 - Published in Atmos. Chem. Phys. Discuss.: 26 September 2012

Revised: 19 April 2013 - Accepted: 21 April 2013 - Published: 14 May 2013

\begin{abstract}
Coupling between the stratosphere and the troposphere allows changes in stratospheric ozone abundances to affect tropospheric chemistry. Large-scale effects from such changes on chemically produced tropospheric aerosols have not been systematically examined in past studies. We use a composition-climate model to investigate potential past and future impacts of changes in stratospheric ozone depleting substances (ODS) on tropospheric oxidants and sulfate aerosols. In most experiments, we find significant responses in tropospheric photolysis and oxidants, with small but significant effects on methane radiative forcing. The response of sulfate aerosols is sizeable when examining the effect of increasing future nitrous oxide $\left(\mathrm{N}_{2} \mathrm{O}\right)$ emissions. We also find that without the regulation of chlorofluorocarbons (CFCs) through the Montreal Protocol, sulfate aerosols could have increased by 2050 by a comparable amount to the decreases predicted due to relatively stringent sulfur emissions controls. The individual historical radiative forcings of CFCs and $\mathrm{N}_{2} \mathrm{O}$ through their indirect effects on methane $\left(-22.6 \mathrm{~mW} \mathrm{~m}^{-2}\right.$ for CFCs and $-6.7 \mathrm{~mW} \mathrm{~m}^{-2}$ for $\left.\mathrm{N}_{2} \mathrm{O}\right)$ and sulfate aerosols $\left(-3.0 \mathrm{~mW} \mathrm{~m}^{-2}\right.$ for CFCs and $+6.5 \mathrm{~mW} \mathrm{~m}^{-2}$ for $\mathrm{N}_{2} \mathrm{O}$ when considering the direct aerosol effect) discussed here are non-negligible when compared to known historical ODS forcing. Our results stress the importance of accounting for stratosphere-troposphere, gas-aerosol and composition-climate interactions when investigating the effects of changing emissions on atmospheric composition and climate.
\end{abstract}

\section{Introduction}

Stratospheric ozone $\left(\mathrm{O}_{3}\right)$ changes have been large over the past few decades mainly due to anthropogenic emissions of ozone depleting substances (ODS), and are expected to be large in the future due to the phase-out of ODS emissions and to climate change (e.g. Austin et al., 2010; Eyring et al., 2010). Stratospheric ozone exerts direct radiative forcing on the Earth system (Forster et al., 2007), while it also indirectly affects other climate aspects such as tropospheric circulation and precipitation (Son et al., 2008; Kang et al., 2011). Furthermore, its changes can impact other radiatively important species, especially by affecting the tropospheric oxidizing capacity. The latter is largely determined by the abundances of hydroxyl radicals $(\mathrm{OH})$, which depend on tropospheric ozone and nitrogen oxides $\left(\mathrm{NO}_{\mathrm{x}}\right)$, humidity, abundances of species that consume $\mathrm{OH}$ (carbon monoxide $(\mathrm{CO})$, methane and non-methane volatile organic compounds (NMVOCs)), and ultra-violet (UV) radiation (e.g. Thompson, 1992; Spivakovsky et al., 2000; Lelieveld et al., 2002; Voulgarakis et al., 2013).

Changes in stratospheric ozone can affect tropospheric oxidants via stratosphere-troposphere exchange (STE) (Collins et al., 2003; Hegglin and Shepherd, 2009; Prather and Hsu, 2010; Zeng et al., 2010; Voulgarakis et al., 2011), which enriches the troposphere with ozone, and by driving changes in the photolysis of tropospheric species (Madronich and Granier, 1992; Bekki et al., 1994; Fuglestved et al., 1994; Krol and van Weele, 1997; Isaksen et al., 2005; Lamarque et al., 2010a; Tang et al., 2011), which depends on UV radiation and, thus, the amount of overhead ozone (e.g. increased stratospheric ozone columns can lead to less tropospheric 
$\mathrm{OH})$. Photolysis has a central role in driving the formation of OH (Madronich and Granier, 1992; Fuglestved et al., 1994; Thompson, 1992; Rohrer and Berresheim, 2006; Voulgarakis et al., 2009), since it leads to the breakdown of ozone,

$\mathrm{O}_{3}+\mathrm{h} v \rightarrow \mathrm{O}_{2}+\mathrm{O}\left({ }^{1} \mathrm{D}\right)(\lambda<320 \mathrm{~nm})$

and the excited oxygen atoms produced react with water vapor to produce $\mathrm{OH}$ :

$\mathrm{O}\left({ }^{1} \mathrm{D}\right)+\mathrm{H}_{2} \mathrm{O} \rightarrow \mathrm{OH}+\mathrm{OH}$.

Apart from cleansing the atmosphere from pollutants such as $\mathrm{CO}$ and NMVOCs, oxidation by $\mathrm{OH}$ also affects methane and sulfate aerosols, being the major sink of the former (Madronich and Granier, 1992; Voulgarakis et al., 2013) and a major chemical source of the latter via gaseous oxidation of sulfur dioxide $\left(\mathrm{SO}_{2}\right)$ (Unger et al., 2006; Shindell et al., 2009). Thus, OH plays a significant indirect role in determining the radiative balance of the troposphere. Sulfate aerosols are also produced through $\mathrm{SO}_{2}$ aqueous oxidation by hydrogen peroxide $\left(\mathrm{H}_{2} \mathrm{O}_{2}\right)$ (Koch et al., 2006; Unger et al., 2006), and the production/loss of the latter also heavily depends on photolysis (e.g. Lelieveld et al., 2002). Sulfate aqueous-phase production is globally more efficient than the gas-phase process (via $\mathrm{OH}$ ), but the former produces aerosols with shorter lifetime, due to the usual simultaneous presence of clouds.

Although effects of stratospheric ozone changes on tropospheric oxidants have been studied in the past (see above), their possible indirect link with tropospheric aerosols and their radiative forcing has not been examined. Here, we systematically explore these links in a number of model experiments, considering both past and future ODS changes. We further investigate such stratosphere-troposphere interactions in a hypothetical future scenario where ODS have not been regulated by the Montreal Protocol. Past studies examining this topic did not investigate tropospheric effects (Morgenstern et al., 2008; Newman et al., 2009). In Sect. 2, we outline the main characteristics of the model used, and describe the model experiments performed. Section 3 presents and discusses the results of the experiments, while Sect. 4 outlines the conclusions of this study.

\section{Model description and experimental set-up}

\subsection{Model description}

We used a version of the GISS composition-climate model (Shindell et al., 2006, 2013a), which is almost identical to the ModelE2 version developed for use in simulations in support of the Intergovernmental Panel on Climate Change (IPCC) Fifth Assessment Report (AR5). The benefit of using a composition climate-model as opposed to a chemistrytransport model (CTM) is that the radiative forcing of the perturbations applied can be diagnosed immediately, without the need of extra radiative transfer calculations. The model has a $2^{\circ}$ latitude by $2.5^{\circ}$ longitude horizontal resolution and 40 vertical layers from the surface to $0.1 \mathrm{hPa}$. Tropospheric/stratospheric chemistry includes 156 chemical reactions among 51 gas species. Photolysis rates are simulated using the Fast-J2 scheme (Wild et al., 2000; Bian and Prather, 2002), which accounts for the effects of modelled overhead ozone, clouds, aerosols and surface reflections. Aerosol tracers include sulfate (Koch et al., 2006, 2007), nitrate (Bauer et al., 2007), elemental and organic carbon, sea salt (Koch et al., 2006) and dust (Miller et al., 2006), while we also include aerosol indirect effects based on Menon et al. $(2008,2010)$. The model's sulfate aerosol scheme includes prognostic simulations of the mass distributions of dimethyl sulfide (DMS), methanesulfonic acid (MSA), $\mathrm{SO}_{2}$, and sulfate (Koch et al., 2006). The sulfate lifetime in the model is equal to 3 days.

The model's skill in capturing tropospheric oxidants and sulfate has been evaluated in past studies and shown to be realistic (Koch et al., 2006; Shindell et al., 2006). A recent model evaluation, in which a very similar version of the model was used (Shindell et al., 2013a), showed that the model has improved significantly compared to its previous version (Shindell et al., 2006) when it comes to ozone seasonality in the stratosphere. However, the Antarctic ozone hole extends more equatorward than seen in the observations, and it lasts somewhat too long. Still, the total ozone biases in middle and low latitudes, which are of particular interest in this study (due to the abundance of oxidants and aerosols in these regions), are small, and typically less than $5 \%$. In addition, the model's aerosol performance has thoroughly been evaluated against surface and satellite observations as part of the Atmospheric Chemistry and Climate Modeling Intercomparison Project (ACCMIP; Shindell et al., 2013b). The model's performance was fairly satisfactory, with biases against AeroNet measurements being among the lowest in the multi-model set, particularly over Europe and North America. This is important, as these regions are key for the responses we are examining. Performance was less good e.g. over North Africa (overestimates) and over southern midlatitude regions (underestimates), however such regions are less crucial for the current analysis, as sulfate aerosols are not abundant in them.

The global tropospheric mean mass-weighted $\mathrm{OH}$ concentration is $9.9 \times 10^{5}$ molecules $\mathrm{cm}^{-3}$, which is in good agreement with past estimates (Lawrence et al. (2001) found a range of $8.8-11.4 \times 10^{5}$ molecules $\mathrm{cm}^{-3}$ ). Furthermore, it has been shown (Voulgarakis et al., 2013) that the model's tropospheric chemical methane lifetime (10.6 yr) agrees very well with a recent observationally constrained estimate $(11.2 \pm 1.3 \mathrm{yr}$; Prather et al., 2012). The above indicate that tropospheric oxidising capacity is simulated reasonably in the model. The model's sulfate has been found to be more sensitive to $\mathrm{OH}$ changes than several other models (Fry et al., 2012), though these other models did not include liquid tracer budgets (i.e. gas phase and dissolved tracers are not tracked separately), which may mean that they are missing some of 
the physics that are included in the GISS simulations, though differences in sulfate chemistry could be important as well.

\subsection{Experimental set-up}

In the experiments presented here, present-day anthropogenic and biomass burning emissions of $\mathrm{NO}_{\mathrm{x}}, \mathrm{CO}$, NMVOCs and aerosols follow Lamarque et al. (2010b), which were created in support of the Coupled Model Intercomparison Project Phase 5 (CMIP5). Lightning $\mathrm{NO}_{\mathrm{x}}$ emissions depend on the model's convection (Price et al.,

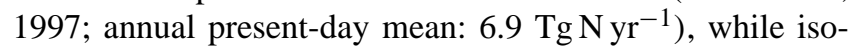
prene emissions respond to temperature and solar radiation based on the algorithm of Guenther et al. (2006) (annual present-day mean: $467 \mathrm{Tg} \mathrm{yr}^{-1}$ ). Natural (nonagriculture) emissions of $\mathrm{NO}_{\mathrm{x}}$ from soils are prescribed at fixed values $\left(2.7 \mathrm{Tg} \mathrm{Nyr}^{-1}\right.$, as in Shindell et al., 2013a; total soil emissions including the agricultural source are equal to $3.4 \mathrm{Tg} \mathrm{Nyr}^{-1}$ ), as are biogenic emissions of alkenes $\left(16 \mathrm{TgC} \mathrm{yr}^{-1}\right)$, paraffins $\left(14 \mathrm{TgC} \mathrm{yr}^{-1}\right)$, and terpenes $\left(192 \mathrm{Tg} \mathrm{yr}^{-1}\right)$. The concentrations of long-lived gases, such as $\mathrm{CO}_{2}$, methane, $\mathrm{N}_{2} \mathrm{O}$ and $\mathrm{CFCs}$, are prescribed at the surface to observed present-day values. When perturbed in our experiments (CFCs, $\mathrm{N}_{2} \mathrm{O}$; see next paragraph), they either follow past observations, or future projections according to the Representative Concentration Pathway (RCP; van Vuuren et al., 2011). The RCP projections for $\mathrm{N}_{2} \mathrm{O}$ and CFC concentrations are based on calculations with the reducedcomplexity coupled carbon cycle climate model MAGICC 6.3 to estimate mixing ratios that would result from the RCP emissions (Meinshausen et al., 2011).

We performed six main simulations (see Table 1), in all of which climatic conditions were kept to present-day levels: (a) BASE, which represents non-perturbed present-day (2000) conditions; (b) 1960CFCs, in which CFCs are set to 1960 levels; (c) 2100CFCs, in which CFCs are set to 2100 levels following the RCP8.5 scenario; (d) WACFCs, in which CFCs are set to 2050 levels following a "world avoided" scenario, where CFCs are not regulated by the Montreal Protocol (Newman et al., 2009); (e) 1850N2O, in which $\mathrm{N}_{2} \mathrm{O}$ is set to 1850 levels; and (f) $2100 \mathrm{~N} 2 \mathrm{O}$, in which $\mathrm{N}_{2} \mathrm{O}$ is set to 2100 levels (following RCP8.5). NonODS emissions/concentrations and sea-surface temperatures (SSTs) are representative of present-day in all experiments in order to isolate the ODS effects alone. Note that allowing ODSs to affect SSTs could have a significant impact on the results, since both CFCs and $\mathrm{N}_{2} \mathrm{O}$ are important climate forcers. In addition to the above six experiments, we also performed a present-day simulation with 2050 RCP4.5 aerosol emissions, for comparison. In each experiment, we ran the model using the same conditions for $7 \mathrm{yr}$ and then averaged in order to increase the signal-to-noise ratio. Two years of spin-up were performed in advance, which we confirmed were enough for the stratospheric concentrations to fully adjust to the perturbations applied at the surface.
Table 1. Percentage (\%) differences in surface CFC and $\mathrm{N}_{2} \mathrm{O}$ concentrations between the various sensitivity experiments and the BASE simulation.

\begin{tabular}{lrr}
\hline & CFCs & $\mathrm{N}_{2} \mathrm{O}$ \\
\hline BASE & 0 & 0 \\
1960CFCs & -94 & 0 \\
$2100 \mathrm{CFCs}$ & -76 & 0 \\
WACFCs & +1026 & 0 \\
$1850 \mathrm{~N} 2 \mathrm{O}$ & 0 & -13 \\
$2100 \mathrm{~N} 2 \mathrm{O}$ & 0 & +38 \\
\hline
\end{tabular}

\section{Results and discussion}

Figure 1 shows the annual zonal mean photolysis rate of ozone to yield a singlet oxygen atom $\left(\mathrm{J}\left(\mathrm{O}^{1} \mathrm{D}\right)\right.$; see Reaction $\mathrm{R} 1$ ), as well as its changes in the various sensitivity experiments. $\mathrm{J}\left(\mathrm{O}^{1} \mathrm{D}\right)$ is largest in the tropics, where solar zenith angles and overhead ozone columns are smallest. We find that all the perturbations applied to ODS have sizeable effects on tropospheric photolysis (Fig. 1). The changes in $\mathrm{J}\left(\mathrm{O}^{1} \mathrm{D}\right)$ are largest over polar regions, where stratospheric processes depleting ozone are more effective, and thus UV changes affecting tropospheric photolysis are also large. However, even in non-polar regions, such as northern midlatitudes, there are sizeable changes (mostly larger than $5 \%$ ), which can have important impacts on tropospheric chemistry. The effects are dramatic in the WACFCs experiment, where midlatitude $\mathrm{J}\left(\mathrm{O}^{1} \mathrm{D}\right)$ increases by more than $120 \%$.

Figure 2 shows differences in total ozone column, surface $\mathrm{J}\left(\mathrm{O}^{1} \mathrm{D}\right)$, surface $\mathrm{OH}$ and surface sulfate concentrations, between the WACFCs and the BASE simulation, for the northern extratropics, the region where sulfate is most important for climate and air quality. Total ozone for 2050 is lower by $50-60 \%$ due to the lack of regulation in CFCs in this scenario, in fairly good agreement with previous work (Newman et al., 2009). This leads to ubiquitous surface $\mathrm{J}\left(\mathrm{O}^{1} \mathrm{D}\right)$ increases of more than $150 \%$ in the northern extratropics, which, in turn leads to $\mathrm{OH}$ increases of $40-80 \%$. The highest $\mathrm{OH}$ increases are located in the regions with the largest total ozone and $\mathrm{J}\left(\mathrm{O}^{1} \mathrm{D}\right)$ changes combined with high $\mathrm{OH}$ recycling efficiencies due to high amounts of $\mathrm{NO}_{\mathrm{x}}$ (Eastern US, Western Europe, East Asia) (Lelieveld et al., 2002).

We find subsequent large increases of sulfate aerosol concentrations throughout the northern extratropics (Fig. 2d). Differences range from 20 to $50 \%$ in highly populated midlatitude regions where aerosols cause serious human health damage. The increases are around 30-35\% over the northernmost states of the US, over $40 \%$ over the British Isles, and $15-30 \%$ over East Asia. Increases in sulfate aerosols are correlated in several cases to the enhancement of the tropospheric oxidizing capacity, as reflected by $\mathrm{OH}$ (e.g. over Pacific and Atlantic pollution outflow regions), which leads to more $\mathrm{SO}_{2}$ oxidised to sulfate. Figure 3 shows the zonal mean 
a

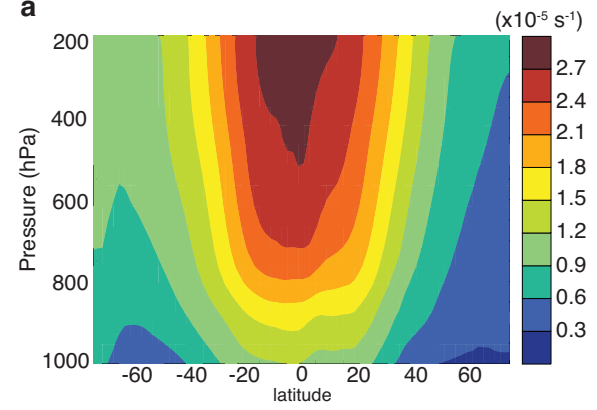

c

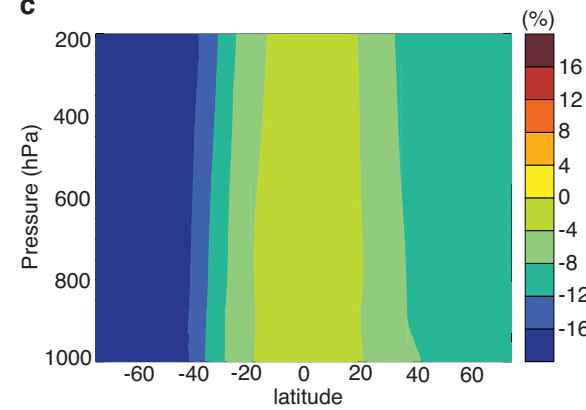

e

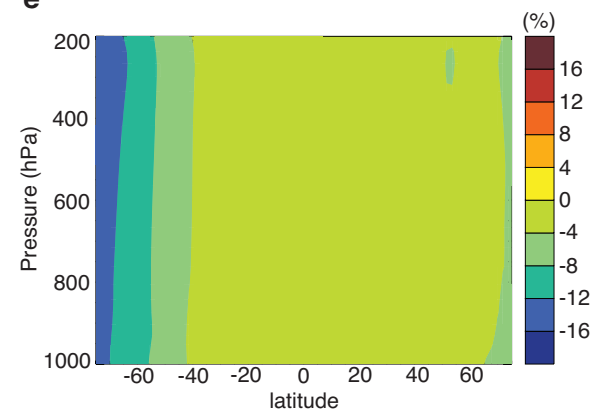

b

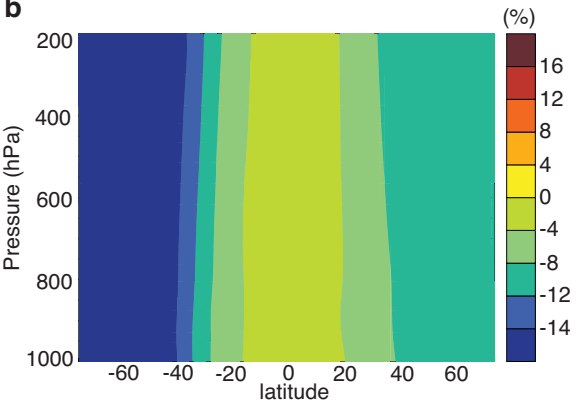

d

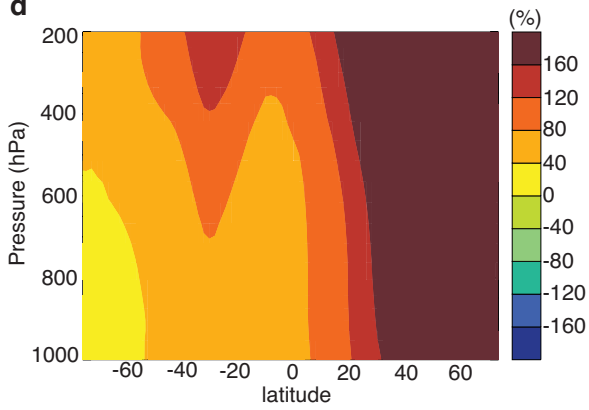

f

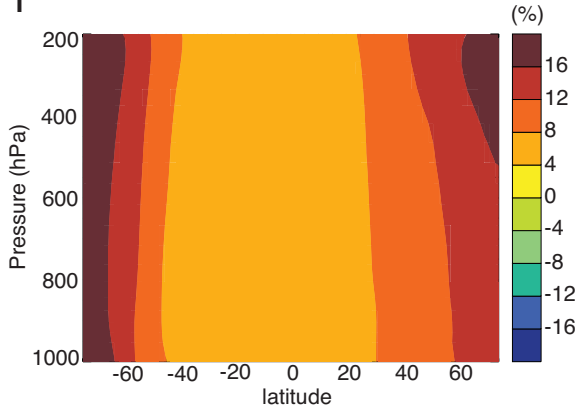

Fig. 1. Photolysis rate changes in the sensitivity experiments. Annual zonal mean $J\left(O^{1} \mathrm{D}\right)$ in the BASE simulation (a), and difference of annual zonal mean $\mathrm{J}\left(\mathrm{O}^{1} \mathrm{D}\right)$ in the 1960CFCs (b), the 2100CFCs (c), the WACFCs (d), the 1850N2O (e) and the $2100 \mathrm{~N} 2 \mathrm{O}(\mathbf{f})$ simulations, from the BASE run. Note the difference in the colour scale in (d).

differences in concentration and chemical gas-phase production rate of sulfate, between WACFCs and BASE. It is clear that areas with large chemical production changes are also areas with high concentration changes, the "hot-spot" being the northern midlatitudes at low altitudes. This finding is in qualitative agreement with an earlier study on a related topic (Toumi et al., 1994).

Note that changes in $\mathrm{H}_{2} \mathrm{O}_{2}$ and aqueous-phase production of sulfate are also detectable in our perturbation experiments, especially in WACFCs, where global mean $\mathrm{H}_{2} \mathrm{O}_{2}$ changes by around $38 \%$, while global mean sulfate aerosol production via $\mathrm{H}_{2} \mathrm{O}_{2}$ changes by $11 \%$ (compared to $28 \%$ for gasphase), relative to BASE. However, as mentioned earlier, the gas-phase production changes (via $\mathrm{OH}$ ) are expected to be more important due to the longer lifetime of the sulfate produced via gaseous processes.

Table 2 summarizes the effects of the perturbations applied in the different experiments on tropospheric $\mathrm{OH}$ and surface sulfate concentration, as well as on radiative forcing by methane and sulfate. Note that sulfate radiative forcing calculations only take the direct aerosol effect into account. We focus on global effects, and on effects in northern midlatitudes, where sulfate is important, both for air quality and climate. The $\mathrm{OH}$ differences are significant in all the experiments, with the WACFCs scenario showing clearly the largest effects (more than an order of magnitude larger than in other simulations), consistent with photolysis changes (Fig. 1). Global methane radiative forcing strongly decreases in WACFCs (by $\sim 0.5 \mathrm{~W} \mathrm{~m}^{-2}$ ) due to tropospheric $\mathrm{OH}$ increases, while there are also significant changes in the other experiments $\left(6-23 \mathrm{~mW} \mathrm{~m}^{-2}\right)$.

For sulfate, in terms of both concentration and forcing, the two cases for which we find the most sizeable relative changes are WACFCs and 2100N2O. In the former, the differences range from around 12 to $20 \%$, while in the latter, they are around 1.7-2.5\%. Regionally, concentration 

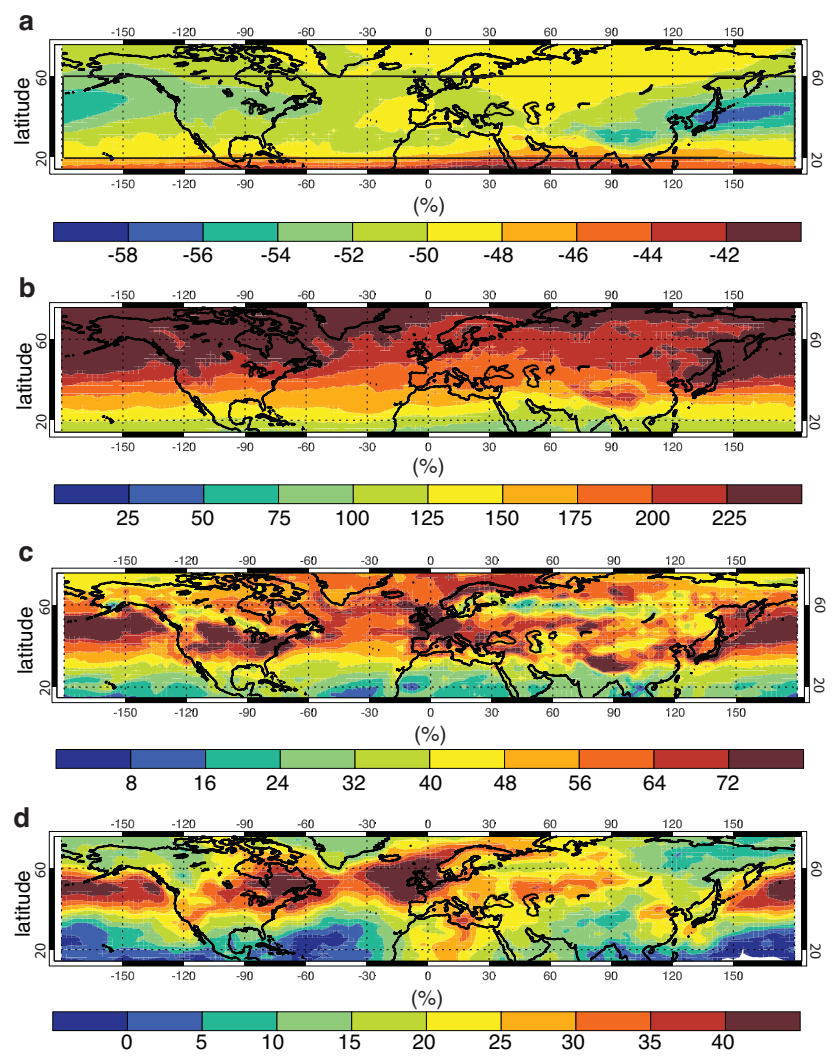

Fig. 2. Differences in annual mean total ozone column (a), $\mathrm{J}\left(\mathrm{O}^{1} \mathrm{D}\right)$ (b), $\mathrm{OH}$ (c) and sulfate concentration (d), between WACFCs and BASE. All differences are in percent $(\%)$, and for $\mathrm{J}\left(\mathrm{O}^{1} \mathrm{D}\right), \mathrm{OH}$ and sulfate they refer to the surface. Solid lines in (a) denote the midlatitude region $\left(20-60^{\circ} \mathrm{N}\right)$ analysed in Table 2.

differences can be as large as $50 \%$ in WACFCs and $15 \%$ in $2100 \mathrm{~N} 2 \mathrm{O}$, and forcing differences reach $35 \%$ in WACFCs and $13 \%$ in $2100 \mathrm{~N} 2 \mathrm{O}$ (see Fig. $2 \mathrm{~d}$ and Fig. 4), with a fairly good correspondence of high response regions in the two scenarios (e.g. north Atlantic, East Asia, northwestern Pacific). Areas affected heavily include East Asia, parts of Europe and parts of Northeastern America and the North Atlantic. Note though that for $2100 \mathrm{~N} 2 \mathrm{O}$, the radiative forcing differences (Fig. 4a) are only significant where the signal is relatively strong (e.g. East Asia). An unexpected feature is that for the $1850 \mathrm{~N} 2 \mathrm{O}$ simulation, sulfate is higher than in BASE (see Table 2), despite the fact that there is less $\mathrm{OH}$ in the atmosphere. However, this effect is rather small and is likely related to meteorological feedbacks resulting from atmospheric forcing, or to unforced variability.

In an additional experiment where sulfur emissions were set to 2050 values following the RCP4.5 scenario (in which $\mathrm{SO}_{2}$ emissions decrease by more than $50 \%$ ) but ODSs were kept to present-day levels, we found global surface sulfate aerosol concentration reductions of $24 \%$. This indicates that the indirect effect of ODS on aerosols discussed here $(17 \%$ globally) could have cancelled out part of the benefit gained a

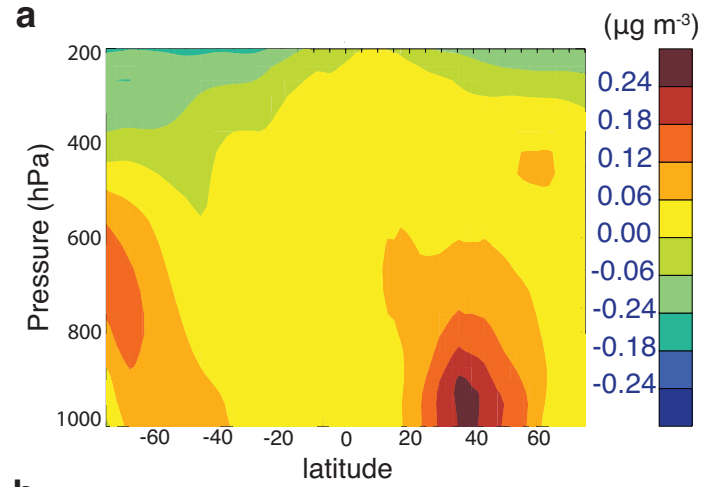

b

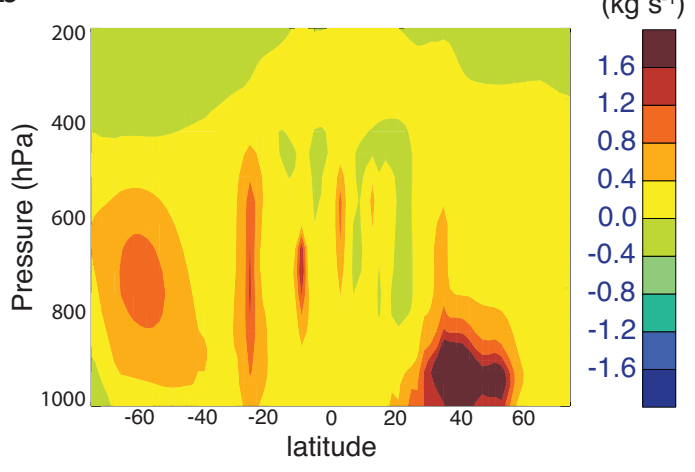

Fig. 3. Annual zonal mean differences in sulfate concentration (a) and gas-phase production (via $\mathrm{OH})(\mathbf{b})$, between WACFCs and BASE.

from aerosol emissions reductions, had the Montreal Protocol not been implemented. Another interesting feature is that several of the changes that we document here would likely cancel out, at least partially, in a future scenario including both $\mathrm{CFC}$ and $\mathrm{N}_{2} \mathrm{O}$ changes (compare 2100CFCs and $2100 \mathrm{~N} 2 \mathrm{O}$ columns in Table 2). However, in such a case the dominant driver of future changes would be expected to be the large sulfur emission decreases in scenarios such as RCP8.5. Note that total sulfate burden changes depend on the current relative amount of $\mathrm{SO}_{2}$ removed by deposition versus conversion to sulfate, thus it would be useful to test the variation of this balance across different models in future work (in our model, the $\mathrm{SO}_{2}$ deposited globally is about double the amount that is chemically converted).

The indirect radiative forcing of ODSs through the processes presented here has not been discussed in previous studies (Forster et al., 2007). We compared these effects to the magnitude of previously estimated direct historical ODS forcing, as well as to indirect forcing through other processes. Our calculated global methane radiative forcing due to past CFC changes is equal to about $7 \%$ of the direct preindustrial (PI) to present-day (PD) forcing from CFCs $\left(0.32 \mathrm{~W} \mathrm{~m}^{-2}\right)$, and to $65 \%$ of their indirect effect through stratospheric ozone radiative forcing $\left(-0.04 \mathrm{~W} \mathrm{~m}^{-2}\right)$, based on Forster et al. (2007). For sulfate radiative forcing, the 
Table 2. Differences in annual mean tropospheric $\mathrm{OH}$ concentration, surface sulfate aerosol concentration, methane and sulfate aerosol instantaneous top-of-the-atmosphere (TOA) radiative forcing (RF), between the sensitivity experiments and the BASE run ${ }^{\mathrm{a}}$.

\begin{tabular}{|c|c|c|c|c|c|}
\hline & 1960CFCs & 2100CFCs & WACFCs & $1850 \mathrm{~N} 2 \mathrm{O}$ & $2100 \mathrm{~N} 2 \mathrm{O}$ \\
\hline $\begin{array}{l}\mathrm{GL}^{\mathrm{b}} \text { trop. } \\
\mathrm{OH} \text { conc. } \\
(\%)\end{array}$ & $-3.0 \pm 0.2$ & $-2.7 \pm 0.2$ & $+130.9 \pm 0.8$ & $-0.9 \pm 0.2$ & $+2.2 \pm 0.2$ \\
\hline $\begin{array}{l}\mathrm{GL} \\
\mathrm{CH}_{4} \mathrm{RF}^{\mathrm{d}} \\
\left(\mathrm{mW} \mathrm{m} \mathrm{m}^{-2}\right)\end{array}$ & $+22.6 \pm 1.0$ & $+20.4 \pm 1.5$ & $-515.1 \pm 1.4$ & $+6.7 \pm 1.1$ & $-16.2 \pm 1.0$ \\
\hline $\begin{array}{l}\mathrm{NM}^{b} \text { trop. } \\
\mathrm{OH} \text { conc. }(\%)\end{array}$ & $-2.1 \pm 0.1$ & $-1.8 \pm 0.2$ & $+80.5 \pm 1.0$ & $-1.0 \pm 0.2$ & $+2.7 \pm 0.2$ \\
\hline $\begin{array}{l}\text { GL surf. } \\
\text { Sulfate conc. }^{\mathrm{c}}(\%)\end{array}$ & $-0.3 \pm 0.3$ & $-0.8 \pm 0.3$ & $+17.5 \pm 0.3$ & $+0.5 \pm 0.4$ & $+1.7 \pm 0.4$ \\
\hline $\begin{array}{l}\text { NM surf. } \\
\text { Sulfate conc. (\%) }\end{array}$ & $+0.4 \pm 0.4$ & $-0.5 \pm 0.3$ & $+19.9 \pm 0.4$ & $+1.1 \pm 0.5$ & $+2.4 \pm 0.6$ \\
\hline $\begin{array}{l}\text { GL } \\
\text { Sulfate } \mathrm{RF}^{\mathrm{c}, \mathrm{e}} \\
\left(\mathrm{mW} \mathrm{m}^{-2}\right)\end{array}$ & $+3.0 \pm 1.6$ & $+6.0 \pm 2.2$ & $-83.9 \pm 1.7$ & $-6.5 \pm 1.6$ & $-12.1 \pm 2.6$ \\
\hline $\begin{array}{l}\text { NM } \\
\text { Sulfate RF } \\
\left(\mathrm{mW} \mathrm{m}^{-2}\right)\end{array}$ & $-3.7 \pm 2.8$ & $+2.6 \pm 6.5$ & $-157.2 \pm 4.1$ & $-17.4 \pm 6.0$ & $-18.3 \pm 7.3$ \\
\hline
\end{tabular}

a Seven years from each simulation were averaged in order to increase the signal-to-noise ratio. The uncertainties are $\pm 1 \sigma$ standard deviations of the mean, based on the fluctuations among the different years in each simulation. CFCs and $\mathrm{N}_{2} \mathrm{O}$ concentrations for 2100 follow the RCP8.5 scenario.

${ }^{\mathrm{b}} \mathrm{GL}=$ global; $\mathrm{NM}=$ northern midlatitudes $\left(20-60^{\circ} \mathrm{N}\right)$.

${ }^{c}$ Mean tropospheric $\mathrm{OH}$ concentrations used for calculating the differences are mass-weighted, while mean surface sulfate concentrations and mean sulfate radiative forcings are area-weighted.

${ }^{d}$ We infer approximate global methane changes offline to calculate methane radiative forcing changes presented in Table 2. Global methane is calculated from global $\mathrm{OH}$ changes assuming a liner relationship between $\mathrm{OH}$ and methane chemical loss, and an additional chemical feedback $(\delta \ln (\mathrm{OH}) / \delta \ln (\mathrm{CH} 4)=-0.32$; Prather et al., 2001). Methane radiative forcing was calculated following the standard formulations used in the IPCC Third Assessment Report (TAR; Prather et al., 2001).

e Sulfate direct instantaneous radiative forcing is calculated online as average over time during the simulations, with radiative transfer calculations performed twice at each point in time with the only difference in the two calculations being the sulfate field

CFC effects here are smaller and less significant $(1 \%$ of the direct $\mathrm{CFC}$ forcing and $8 \%$ of the their indirect forcing through stratospheric ozone changes). The historical indirect effects of $\mathrm{N}_{2} \mathrm{O}$ on radiative forcing through methane and sulfate (roughly equal) are equal to around $5 \%$ of its direct PI-PD forcing $\left(0.15 \mathrm{~W} \mathrm{~m}^{-2}\right)$ and to $70 \%$ of its indirect effects through stratospheric ozone changes $\left(-0.01 \mathrm{~W} \mathrm{~m}^{-2}\right)$. The effects of future $\mathrm{N}_{2} \mathrm{O}$ changes on radiative forcing in our experiments are 2-3 times larger than the historical effects (due to the larger increases in 2000-2100 compared to 1850-2000), while the future effects of CFCs are also equal or larger to the historical.

Changes in stratospheric ozone can impact tropospheric oxidation via STE, and this effect is expected to be opposite of the photolysis effect. Less ozone in the stratosphere can lead to less ozone transported to the troposphere and, thus, less $\mathrm{OH}$ produced by ozone photolysis. However, the effect of UV changes on photolysis appears to be dominating the $\mathrm{OH}$ responses that we find in the troposphere. There is even one case (WACFCs, Southern Hemisphere) in which ozone depletion in the stratosphere is followed by ozone increases in the troposphere. However, this is driven by large increases of tropical/southern sub-tropical stratospheric $\mathrm{NO}_{\mathrm{x}}$
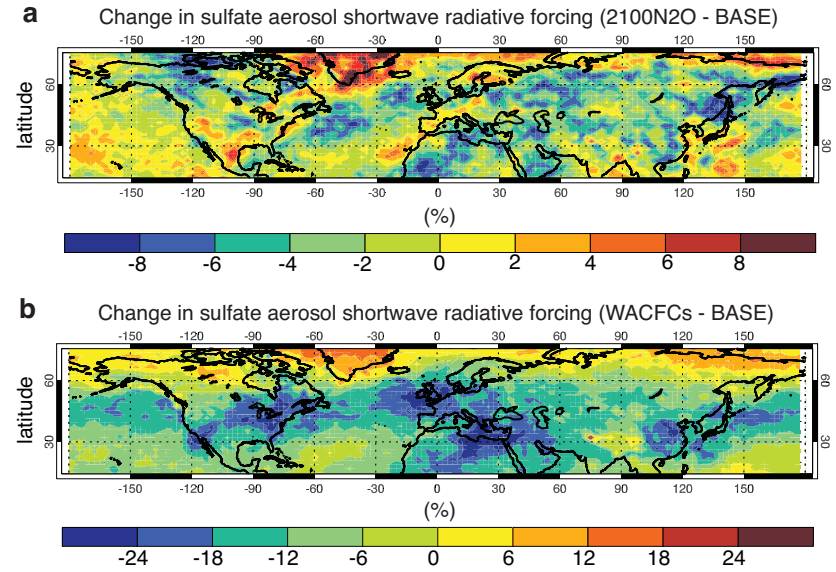

Fig. 4. Changes in sulfate radiative forcing. Annual mean difference of midlatitude sulfate aerosol radiative forcing (shortwave, top-ofthe-atmosphere) in the $2100 \mathrm{~N} 2 \mathrm{O}$ (a) and the WACFCs (b) simulations, from the BASE run. Note that changes are statistically significant only for isolated regions in the mid-north Atlantic, Mediterranean and northern East Asia in (a), but for almost all mid-latitude regions in (b). 
subsequently transported into the Southern Hemisphere troposphere (also see Fig. 1d for effect of this feature on photolysis). It remains unclear whether this feature is realistic, as stratosphere-troposphere chemical interactions in a "worldavoided" scenario have not been examined in other studies. Note that we find that tropospheric temperature and humidity changes are very minimal $(<1 \%)$ in all the experiments (which is expected since we have fixed SSTs/sea ice to present-day values), so we rule out the possibility that climate changes induced by differences in CFCs and stratospheric ozone drive any of the changes simulated.

Our experiments presented here are idealised, since a scenario in which only ODS will change, while other aspects of the climate system remain constant is not realistic. Nevertheless, by isolating the ODS effect, we provide insight into particular processes which can be important. For the two scenarios in which we found the most sizeable differences (WACFCs and 2100N2O), changing future emissions of gases that affect tropospheric oxidation chemistry and climate change would be expected to add to the effects of ODS on aerosols. In particular, studies have found that continental regions, where sulfate aerosols are of high importance, will likely experience increases in $\mathrm{OH}$ abundances due to increases in $\mathrm{NO}_{\mathrm{x}}$ emissions (e.g. SRES A1B and A2 scenarios; see Nakićenović et al., 2000), while the global temperature and humidity increases expected due to global warming may lead to generally more $\mathrm{OH}$ production in the troposphere (Wild and Palmer, 2008). This, in addition to the oxidant increases due to ODS effects found here, could lead to even larger sulfate responses in WACFCs and 2100N2O. Note though, that when more optimistic scenarios are used for future $\mathrm{NO}_{\mathrm{x}}$ emissions (such as in the RCP scenarios; van Vuuren et al., 2011), there is a mixture of positive and negative $\mathrm{OH}$ responses over industrialised regions, with large inter-model variability (Voulgarakis et al., 2013). Furthermore, both sulfur and $\mathrm{NO}_{\mathrm{x}}$ emissions may shift closer to the tropics in the future, which implies that some of the effects at lower latitudes may be more important than we find here.

Projected increases in tropical upwelling could lead to further lower stratospheric ozone decreases at low latitudes (Eyring et al., 2010), which would, again, add to the UV, oxidant and sulfate aerosol responses. Also, projected changes in atmospheric circulation may drive increased transport of ozone from the stratosphere to the troposphere (Collins et al., 2003; Shindell et al., 2006), increasing tropospheric $\mathrm{OH}$ production. However, in a scenario like $2100 \mathrm{~N} 2 \mathrm{O}$, if we account for the simultaneous decline in CFCs, part of the tropospheric effects will be cancelled out. Finally, note that in the calculations of $\mathrm{OH}$ and sulfate responses, feedbacks on $\mathrm{OH}$ through changes in methane have not been taken into account, since methane concentrations were kept constant. Had these feedbacks been included, all responses presented here would have been stronger. For example, only due to the induced methane decreases in WACFCs, global $\mathrm{OH}$ would have dropped by $36 \%$.

\section{Conclusions}

We performed model experiments to investigate the role of ozone depleting substances in driving changes in tropospheric oxidants, aerosols and radiative forcing. These links have not been examined in previous studies investigating the effects of ODS or the evolution of tropospheric aerosols. Our results indicate that changes in ODS and stratospheric ozone can induce large-scale changes in tropospheric composition, with a non-negligible effect on radiative forcing. Indirect historical forcings of CFCs and $\mathrm{N}_{2} \mathrm{O}$ through their effects on tropospheric methane and sulfate range from $8 \%$ to $70 \%$ (depending on the species) of the known corresponding indirect forcings through stratospheric ozone depletion. Special attention is needed regarding $\mathrm{N}_{2} \mathrm{O}$ effects beyond 2100 , since its emissions are expected to be the dominant driver of future stratospheric ozone depletion (Ravishankara et al., 2009). However, we also note that the future effects of $\mathrm{N}_{2} \mathrm{O}$ and CFCs are of opposite signs and may thus partly cancel out.

Our analysis also suggests that CFCs emissions reductions resulting from the Montreal Protocol may be translating to tropospheric composition and climate changes that have not been discussed in assessments exploring the "sideeffects" of the agreement (Velders et al., 2007). We suggest that the Montreal Protocol may have been a factor mediating sulfate aerosol concentrations, especially when considering effects later in the 21st century. Finally, our results imply that accounting for stratosphere-troposphere, gas-aerosol and composition-climate interactions (not fully considered here) is important when assessing the impact of regulations in emissions. Earth system models, which are designed to include all the above-mentioned interactions, are expected to facilitate such efforts in the future.

Acknowledgements. The authors wish to thank Paul Newman for providing useful information on the WACFCs scenario, and NASA ACMAP for funding this research.

Edited by: C. H. Song

\section{References}

Austin, J., Scinocca, J., Plummer, D., Oman, L., Waugh, D., Akiyoshi, H., Bekki, S., Braesicke, P., Butchart, N., Chipperfield, M., Cugnet, D., Dameris, M., Dhomse, S., Eyring, V., Frith, S., Garcia, R. R., Garny, H., Gettelman, A., Hardiman, S. C., Kinnison, D., Lamarque, J. F., Mancini, E., Marchand, M., Michou, M., Morgenstern, O., Nakamura, T., Pawson, S., Pitari, G., Pyle, J., Rozanov, E., Shepherd, T. G., Shibata, K., Teyssedre, H.,Wilson, R. J., and Yamashita, Y.: Decline and recovery of total column ozone using a multimodel time series analysis, J. Geophys. Res., 115, D00M10, doi:10.1029/2010JD013857, 2010.

Bauer, S. E., Koch, D., Unger, N., Metzger, S. M., Shindell, D. T., and Streets, D. G.: Nitrate aerosols today and in 2030: a 
global simulation including aerosols and tropospheric ozone, Atmos. Chem. Phys., 7, 5043-5059, doi:10.5194/acp-7-5043-2007, 2007.

Bekki, S., Law, K. S., and Pyle, J. A.: Effect of ozone depletion on atmospheric $\mathrm{CH}_{4}$ and $\mathrm{CO}$ concentrations, Nature, 371, 595-597, 1994.

Bian, H. and Prather, M.: Fast-J2: Accurate simulations of photolysis in global climate models, J. Atmos. Chem., 41, 281-296, 2002.

Collins, W. J., Derwent, R. G., Garnier, B., Johnson, C. E., Sanderson, M. G., and Stevenson, D. S.: Effect of stratospheretroposphere exchange on the future tropospheric ozone trend, J. Geophys. Res., 108, 8528, doi:10.1029/2002JD002617, 2003.

Ehhalt, D., Prather, M., Dentener, F., Derwent, R., Dlugokencky, E., Holland, E., Isaksen, I., Katima, J., Kirchhoff, V., Matson, P., Midgley, P., and Wang, M.: Atmospheric Chemistry and Greenhouse Gases, in: Climate Change 2001: The Scientific BasisContribution of Working Group I to the Third Assessment Report of the Intergovernmental Panel on Climate Change, edited by: Houghton, J. T., Ding, Y., Griggs, D. J., Noguer, M., van der Linden, P. J., Dai, X., Maskell, K., and Johnson, C. A.,, Cambridge Univ. Press, Cambridge, UK, 2001.

Eyring, V., Cionni, I., Bodeker, G. E., Charlton-Perez, A. J., Kinnison, D. E., Scinocca, J. F., Waugh, D. W., Akiyoshi, H., Bekki, S., Chipperfield, M. P., Dameris, M., Dhomse, S., Frith, S. M., Garny, H., Gettelman, A., Kubin, A., Langematz, U., Mancini, E., Marchand, M., Nakamura, T., Oman, L. D., Pawson, S., Pitari, G., Plummer, D. A., Rozanov, E., Shepherd, T. G., Shibata, K., Tian, W., Braesicke, P., Hardiman, S. C., Lamarque, J. F., Morgenstern, O., Pyle, J. A., Smale, D., and Yamashita, Y.: Multimodel assessment of stratospheric ozone return dates and ozone recovery in CCMVal-2 models, Atmos. Chem. Phys., 10, 94519472, doi:10.5194/acp-10-9451-2010, 2010.

Forster, P., Ramaswamy, V., Artaxo, P., Berntsen, T., Betts, R., Fahey, D. W., Haywood, J., Lean, J., Lowe, D. C., Myhre, G., Nganga, J., Prinn, R., Raga, G., Schulz, M., and Van Dorland, R.: Changes in Atmospheric Constituents and in Radiative Forcing, in Climate Change 2007: The Physical Science BasisContribution of Working Group I to the Fourth Assessment Report of the Intergovernmental Panel on Climate Change, edited by: Solomon, S., Qin, D., Manning, M., Chen, Z., Marquis, M., Averyt, K. B., Tignor, M., and Miller, H. L., Cambridge Univ. Press, Cambridge, UK, 2007.

Fry, M. M., Naik, V., West, J. J., Schwarzkopf, M. D., Fiore, A. M., Collins, W. J., Dentener, F. J., Shindell, D. T., Atherton, C., Bergmann, D., Duncan, B. N., Hess, P., MacKenzie, I. A., Marmer, E., Schultz, M. G., Szopa, S., Wild, O., and Zeng, G.: The influence of ozone precursor emissions from four world regions on tropospheric composition and radiative climate forcing, J. Geophys. Res., 117, D07306, doi:10.1029/2011JD017134, 2012.

Fuglestved, J. S., Jonson, J. E., and Isaksen, I. S. A.: Effects of reductions in stratospheric ozone on tropospheric chemistry through changes in photolysis rates, Tellus B, 46, 172-192, 1994.

Guenther, A., Karl, T., Harley, P., Wiedinmyer, C., Palmer, P. I., and Geron, C.: Estimates of global terrestrial isoprene emissions using MEGAN (Model of Emissions of Gases and Aerosols from Nature), Atmos. Chem. Phys., 6, 3181-3210, doi:10.5194/acp-63181-2006, 2006.
Hegglin, M. I. and Shepherd, T. G.: Large climate-induced changes in ultraviolet index and stratosphere-to-troposphere ozone flux, Nature Geosci., 2, 687-691, 2009.

Isaksen, I. S. A., Zerefos, C., Kourtidis, K., Meleti, C., Dalsoren, S. B., Sundet, J. K., Grini, A., Zanis, P., and Balis, D.: Tropospheric ozone changes at unpolluted and semipolluted regions induced by stratospheric ozone changes, J. Geophys. Res., 110, D02302, doi:10.1029/2004JD004618, 2005.

Kang, S. M., Polvani, L. M., Fyfe, J. C., and Sigmond, M.: Impact of polar ozone depletion n subtropical precipitation, Science, 332, 951-954, 2011.

Koch, D., Schmidt, G. A., and Field, C. V.: Sulfur, sea salt and radionuclide aerosols in GISS ModelE, J. Geophys. Res., 111, D06206, doi:10.1029/2004JD005550, 2006.

Koch D., Bond, T. C., Streets, D., Unger, N., and van der Werf, G. R.: Global impacts of aerosols from particular source regions and sectors, J. Geophys. Res., 112, doi:10.1029/2005JD007024, 2007.

Krol, M. C. and van Weele, M.: Implications of variations in photodissociation rates for global tropospheric chemistry, Atmos. Environ., 31, 1257-1273, 1997.

Lamarque, J.-F., McConnell, J. R., Shindell, D. T., Orlando, J. J., and Tyndall, G. S.: Understanding the drivers for the 20th century change of hydrogen peroxide in Antarctic ice-cores, Geophys. Res. Lett., 38, L04810, doi:10.1029/2010GL045992, 2010a.

Lamarque, J.-F., Bond, T. C., Eyring, V., Granier, C., Heil, A., Klimont, Z., Lee, D., Liousse, C., Mieville, A., Owen, B., Schultz, M. G., Shindell, D., Smith, S. J., Stehfest, E., Van Aardenne, J., Cooper, O. R., Kainuma, M., Mahowald, N., McConnell, J. R., Naik, V., Riahi, K., and van Vuuren, D. P.: Historical (1850-2000) gridded anthropogenic and biomass burning emissions of reactive gases and aerosols: methodology and application, Atmos. Chem. Phys., 10, 7017-7039, doi:10.5194/acp10-7017-2010, 2010b.

Lawrence, M. G., Jöckel, P., and von Kuhlmann, R.: What does the global mean $\mathrm{OH}$ concentration tell us?, Atmos. Chem. Phys., 1, 37-49, doi:10.5194/acp-1-37-2001, 2001.

Lelieveld, J., Peters, W., Dentener, F. J., and Krol, M. C.: Stability of tropospheric hydroxyl chemistry, J. Geophys. Res., 107, 4715, doi:10.1029/2002JD002272, 2002.

Madronich, S. and Granier, C.: Impact of recent total ozone changes on tropospheric ozone photodissociation, hydroxyl radicals, and methane trends, Geophys. Res. Lett., 19, 465-467, 1992.

Meinshausen, M., Smith, S. J., Calvin, K., Daniel, J. S., Kainuma, M. L. T., Lamarque, J.-F., Matsumoto, K., Montzka, S., Raper, S., Riahi, K., Thomson, A., Velders, G. J. M., and van Vuuren, D. P.: The RCP Greenhouse Gas Concentrations and their Extensions from 1765 to 2300, Climatic Change, 109, 213-241, doi:10.1007/s10584-011-0156-z, 2011.

Menon, S., Unger, N., Koch, D., Francis, J., Garrett, T., Sednev, I., Shindell, D., and Streets, D.: Aerosol climate effects and air quality impacts from 1980 to 2030, Environ. Res. Lett., 3, 024004, 12 pp., doi:10.1088/1748-9326/3/2/024004, 2008.

Menon, S., Koch, D., Beig, G., Sahu, S., Fasullo, J., and Orlikowski, D.: Black carbon aerosols and the third polar ice cap, Atmos. Chem. Phys., 10, 4559-4571, doi:10.5194/acp-10-4559-2010, 2010.

Miller, R. L., Schmidt, G. A., and Shindell, D. T., Forced annular variations in the 20th century Intergovernmental Panel on 
Climate Change Fourth Assessment Report models. J. Geophys. Res., 111, D18101, doi:10.1029/2005JD006323, 2006.

Morgenstern, O., Braesicke, P., Hurwitz, M. M., O'Connor, F. M., Bushell, A. C., Johnson, C. E., and Pyle, J. A.: The World Avoided by the Montreal Protocol, Geophys. Res. Lett., 35, L16811, doi:10.1029/2008GL034590, 2008.

Nakićenović, N., Alcamo, J., Davis, G., de Vries, B., Fenhann, J., Gaffin, S., Gregory, K., Grübler, A., Jung, T. Y., Kram, T., La Rovere, E. L., Michaelis, L., Mori, S., Morita, T., Pepper, W., Pitcher, H., Price, L., Riahi, K., Roehrl, A., Rogner, H.-H., Sankovski, A., Schlesinger, M., Shukla, P., Smith, S., Swart, R., van Rooijen, S., Victor, N., and Dadi, Z.: Special Report on Emission Scenarios, edited by: Nakicenovic, N. and Swart, R., 599 pp., Cambridge Univ. Press, New York, 2000.

Newman, P. A., Oman, L. D., Douglass, A. R., Fleming, E. L., Frith, S. M., Hurwitz, M. M., Kawa, S. R., Jackman, C. H., Krotkov, N. A., Nash, E. R., Nielsen, J. E., Pawson, S., Stolarski, R. S., and Velders, G. J. M.: What would have happened to the ozone layer if chlorofluorocarbons (CFCs) had not been regulated?, Atmos. Chem. Phys., 9, 2113-2128, doi:10.5194/acp-9-2113-2009, 2009.

Prather, M. J. and Hsu, J.: Coupling of Nitrous Oxide and Methane by Global Atmospheric Chemistry, Science, 330, 952-954, 2010.

Prather, M. J., Holmes, C. D., and Hsu, J.: Reactive greenhouse gas scenarios: Systematic exploration of uncertainties and the role of atmospheric chemistry, Geophys. Res. Lett., 39, L09803, doi:10.1029/2012GL051440, 2012.

Price, C., Penner, J., and Prather, M.: $\mathrm{NO}_{\mathrm{x}}$ from lightning, 1, Global distribution based on lightning physics, J. Geophys. Res., 102, 5929-5941, 1997.

Ravishankara, A. R., Daniel, J. S., and Portmann, R. W.: Nitrous Oxide $\left(\mathrm{N}_{2} \mathrm{O}\right)$ : The Dominant Ozone-Depleting Substance Emitted in the 21st Century, Science, 326, 123-125, 2009.

Rohrer, F. and Berresheim, H.: Strong correlation between levels of tropospheric hydroxyl radicals and solar ultraviolet radiation, Nature, 442, 184-187, 2006.

Shindell, D. T., Faluvegi, G., Unger, N., Aguilar, E., Schmidt, G. A., Koch, D. M., Bauer, S. E., and Miller, R. L.: Simulations of preindustrial, present-day, and 2100 conditions in the NASA GISS composition and climate model G-PUCCINI, Atmos. Chem. Phys., 6, 4427-4459, doi:10.5194/acp-6-4427-2006, 2006.

Shindell, D. T., Faluvegi, G., Koch, D. M., Schmidt, G. A., Unger, N., and Bauer, S. E.: Improved Attribution of Climate Forcing to Emissions, Science, 326, 716-718, 2009.

Shindell, D. T., Pechony, O., Voulgarakis, A., Faluvegi, G., Nazarenko, L., Lamarque, J.-F., Bowman, K., Milly, G., Kovari, B., Ruedy, R., and Schmidt, G. A.: Interactive ozone and methane chemistry in GISS-E2 historical and future climate simulations, Atmos. Chem. Phys., 13, 2653-2689, doi:10.5194/acp-13-26532013, 2013a.

Shindell, D. T., Lamarque, J.-F., Schulz, M., Flanner, M., Jiao, C., Chin, M., Young, P. J., Lee, Y. H., Rotstayn, L., Mahowald, N., Milly, G., Faluvegi, G., Balkanski, Y., Collins, W. J., Conley, A. J., Dalsoren, S., Easter, R., Ghan, S., Horowitz, L., Liu, X., Myhre, G., Nagashima, T., Naik, V., Rumbold, S. T., Skeie, R., Sudo, K., Szopa, S., Takemura, T., Voulgarakis, A., Yoon, J.-H., and Lo, F.: Radiative forcing in the ACCMIP historical and future climate simulations, Atmos. Chem. Phys., 13, 2939-2974, doi:10.5194/acp-13-2939-2013, 2013b.

Son, S.-W., Polvani, L. M., Waugh, D. W., Akiyoshi, H., Garcia, R., Kinnison, D., Pawson, S., Rozanov, E., Shepherd, T. G., and Shibata, K.: The Impact of Stratospheric Ozone Recovery on the Southern Hemisphere Westerly Jet, Science, 320, 1486-1489, 2008.

Spivakovsky, C. M., Logan, J. A., Montzka, S. A., Balkanski, Y. J., Foreman-Fowler, M., Jones, D. B. A., Horowitz, L. W., Fusco, A. C., Brenninkmeijer, C. A. M., Prather, M. J., Wofsy, S. C., and McElroy, M. B.: Three-dimensional climatological distribution of tropospheric OH: Update and evaluation, J. Geophys. Res., 105, 8931-8980, 2000.

Tang, X., Wilson, S. R., Solomon, K. R., Shao, M., and Madronich, S.: Changes in air quality and tropospheric composition due to depletion of stratospheric ozone and interactions with climate, Photochem. Photobiol. Sci., 10, 280-291, 2011.

Thompson, A. M.: The Oxidizing Capacity of the Earth's Atmosphere: Probable Past and Future Changes, Science, 256, 1157$1165,1992$.

Toumi, R., Bekki, S., and Law, K. S.: Indirect influence of ozone depletion on climate forcing by clouds, Nature, 372, 348-351, 1994.

Unger, N., Shindell, D. T., Koch, D. M., and Streets, D. G.: Cross influences of ozone and sulfate precursor emissions changes on air quality and climate, P. Natl. Acad. Sci., 103, 4377-4380, 2006.

van Vuuren, D. P., Edmonds, J., Kainuma, M., Riahi, K., Thomson, A., Hibbard, K., Hurtt, G. C., Kram, T., Krey, V., Lamarque, J.F., Matsui, T., Meinshausen, M., Nakicenovic, N., Smith, S. J., and Rose S. K.: The Representative Concentration Pathways: An overview, Clim. Change, 109, 5-31, doi:10.1007/s10584-0110148-z, 2011.

Velders, G. J. M., Andersen, S. O., Daniel, J. S., Fahey, D. W., and McFarland, M.: The importance of the Montreal Protocol in protecting climate, P. Natl. Acad. Sci., 104, 4814-4819, 2007.

Voulgarakis, A., Wild, O., Savage, N. H., Carver, G. D., and Pyle, J. A.: Clouds, photolysis and regional tropospheric ozone budgets, Atmos. Chem. Phys., 9, 8235-8246, doi:10.5194/acp-9-82352009, 2009.

Voulgarakis, A., Hadjinicolaou, P., and Pyle, J. A.: Increases in global tropospheric ozone following an El Niño event: examining stratospheric ozone variability as a potential driver, Atmos. Sci. Lett., 12, 228-232, 2011.

Voulgarakis, A., Naik, V., Lamarque, J.-F., Shindell, D. T., Young, P. J., Prather, M. J., Wild, O., Field, R. D., Bergmann, D., CameronSmith, P., Cionni, I., Collins, W. J., Dalsøren, S. B., Doherty, R. M., Eyring, V., Faluvegi, G., Folberth, G. A., Horowitz, L. W., Josse, B., MacKenzie, I. A., Nagashima, T., Plummer, D. A., Righi, M., Rumbold, S. T., Stevenson, D. S., Strode, S. A., Sudo, K., Szopa, S., and Zeng, G.: Analysis of present day and future $\mathrm{OH}$ and methane lifetime in the ACCMIP simulations, Atmos. Chem. Phys., 13, 2563-2587, doi:10.5194/acp-13-25632013, 2013.

Wild, O. and Palmer, P. I.: How sensitive is tropospheric oxidation to anthropogenic emissions? Geophys. Res. Lett., 35, L22802, doi:10.1029/2008GL035718, 2008.

Wild, O., Zhu, X., and Prather, M. J.: Fast-J: Accurate simulation of in- and below-cloud photolysis in Global Chemical Models, J. Atmos. Chem., 37, 245-282, doi:10.1023/A:1006415919030, 2000. 
Zeng, G., Morgenstern, O., Braesicke, P., and Pyle, J. A.: Impact of stratospheric ozone recovery on tropospheric ozone and its budget, Geophys. Res. Lett., 37, L09805, doi:10.1029/2010GL042812, 2010. 